\title{
Lawsonite (pseudomorph)-bearing eclogites from the Kamieniec Metamorphic Belt (Sudetes, SW Poland)
}

\author{
SŁAWOMIR ILNICKI ${ }^{1}$, JACEK SZCZEPAŃSKI $^{2}$, XIN
} $\mathrm{ZHONG}^{3}$

${ }^{1}$ Institute of Geochemistry, Mineralogy and Petrology, Faculty of Geology, University of Warsaw, slawomir.ilnicki@uw.edu.pl, Al. Żwirki i Wigury 93, 02089 Warszawa, Poland

${ }^{2}$ Institute of Geological Sciences, University of Wrocław, Maksa Borna 9, 50-204 Wrocław, Poland

${ }^{3}$ Physics of Geological Processes, The Njord Centre, University of Oslo, Norway

Eclogite bodies dispersed in metapelites of the Kamieniec Metamorphic Belt (KMB; NE margin of the Bohemian Massif, SW Poland) were studied for their record of the Variscan prograde metamorphic path. The textural evidence (sodic diopside + albite symlectites, post-lawsonite polymineral pseudomophs comprising clinozoisite/epidote + paragonite + phengite \pm quartz \pm albite; \pm kyanite) and mineral composition (Si-rich white mica up to $3.48 \mathrm{Si}^{4+}$ a.p.f.u., omphacite up to $0.49 \mathrm{X}_{\mathrm{jd}}$ ) suggest HP conditions. This is confirmed by the Raman geobarometry of apatite inclusions in garnet host. The measured maximal residual pressure of apatite inclusion is ca. $0.25 \mathrm{GPa}$, which yields ca. 2.0 GPa entrapment pressure based on an elastic model.

Furthermore, the calculated phase equilibria models support these results, as compositional isopleths for garnet rims, omphacite and white mica point to peak pressures 2.4 $2.6 \mathrm{GPa}$ (at ca. $560^{\circ} \mathrm{C}$ ) preceded by an earlier stage at $1.5-1.6$ $\mathrm{GPa}$ and ca. $350^{\circ} \mathrm{C}$.

The infered presence of lawsonite together with the results of thermodynamic modelling and microRaman geobarometry prove cold conditions of metamorphic progression, which are also shared by the surrounding metapelites of KMB but stand in contrast to warmer HP areas recognized in the Sudetes (the Orlica-Śnieżnik Dome, the Góry Sowie Massif). The reconstructed prograde PT path along ca. $6-7^{\circ} \mathrm{C} / \mathrm{km}$ geotherm shows another facet of the Variscan collision and associated tectonic stacking.

The study was financed by the grant no UMO2015/17/B/ST10/02212 from the National Science Centre, Poland. 